\title{
KOMUNITAS JOLI JOLAN MENCEGAH PERILAKU KONSUMTIF MASYARAKAT DI SOLO
}

\author{
Sarah Dinar Kurniati ${ }^{1}$, Abdul Rahman ${ }^{1 *}$, Yosafat Hermawan Trinugraha ${ }^{1}$ \\ ${ }^{1}$ Universitas Sebelas Maret Surakarta, Indonesia \\ *e-mail: abdul.rahman@staff.uns.ac.id
}

\begin{abstract}
Abstrak
Penggunaan teknologi terus meningkat termasuk promosi online dan pasar digital. Keduanya memudahkan berbelanja menuju perilaku konsumtif. Penelitian ini menggunakan teori Pertukaran Sosial karya Peter Blau untuk membahas komunitas Joli Jolan, yang menawarkan transaksi barang, barter, untuk memperkuat peran sosial dalam mencegah perilaku konsumtif. Tujuan penelitian ini membahas komunitas Joli Jolan sebagai pasar alternatif agar masyarakat tidak berperilaku konsumtif di era digital. Penelitian kualitatif dengan pendekatan studi kasus ini melibatkan dua belas informan, termasuk satu pelopor Joli Jolan, empat anggota tetap, dan tujuh pengunjung. Wawancara, observasi dan dokumentasi telah digunakan dalam mengumpulkan data primer dan sekunder, lalu dianalisis dengan reduksi data, penyajian data, dan penyimpulan. Temuan menegaskan bahwa masyarakat hidup berperilaku konsumtif karena faktor eksternal: pemasaran online, promosi, dan kampanye. Sebagai antitesa baru, komunitas Joli Jolan telah membangkitkan pemasaran konvensional: barter, Food Not Boom, workshop, dan pembagian susu gratis. Pengunjung dan anggota Joli Jolan menikmati suasana kehidupan sosial menyenangkan ini. Mereka menikmati pertukaran barang untuk menghemat uang. Mereka menikmati pembicaraan informal, kesenangan dan makanan gratis dari komunitas Joli Jolan. Mereka juga mengikuti lokakarya untuk memahami perilaku konsumtif dan tata kelola kas keluarga. Anggota Joli Jolan mengapresiasi donasi dari masyarakat dan pengunjung. Dana tersebut kemudian mereka gunakan untuk membina lingkungan masyarakat. Dengan demikian, komunitas Joli Jolan telah menjadi a unique social market yang dipercaya dan berkelanjutan dilakukan oleh dan untuk komunitas.
\end{abstract}

Kata kunci: Barter; Komunitas; Konsumtif; Pemasaran; Sosial

\begin{abstract}
The growing use of technology, including online promotion and digital markets, is easing shopping, leading to consumptive behavior. This study uses the social exchange theory by Peter Blau to discuss the Joli Jolan community, which offers good transactions called barter to strengthen social roles in preventing consumptive behavior. The purpose of this study is to discuss the Joli Jolan community as an alternative in the digital era so that people do not behave consumptively. This qualitative research applied a case study approach involving twelve informants, including one Joli Jolan initiator, four permanent members, and seven visitors. Interview, observation, and documentation methods were used to collect primary and secondary data then analyzed with data reduction, data display, and concluding remarks. The findings asserted that people with consumptive behavior were constructed by external factors: online, promotion, and campaign. Joli Jolan community members have run a series of conventional marketing activities, including barter, Food Not Boom, workshop, and free milk-sharing. Visitors and Joli Jolan members enjoyed goods exchanges to save more money. They enjoy informal talking, fun, and food. They joined the workshop to have a better understanding of consumptive behaviors leading to manageable family cashflows. Joli Jolan members appreciate donations from the community and visitors. They use the funds to foster the community environment. Thus, the Joli Jolan community becomes a unique social market trusted by and for the community.
\end{abstract}

Keywords: Barter; Community; Consumptive; Marketing; Social

This is an open access article under the CC BY-SA license.

Copyright (C) 2021 by Author. Published by Universitas Pendidikan Ganesha.

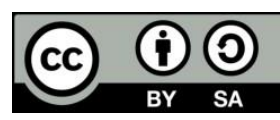

\section{PENDAHULUAN}

Kemajuan teknologi memudahkan

banyak orang memenuhi kebutuhan

hidupnya dan membeli barang dan jasa dari beragam iklan. Promosi menjadikan orang tertarik dan berkeinginan untuk membeli. Terkadang orang membeli suatu barang setelah mengikuti apa yang sedang viral, 
bukan karena kebutuhan, tetapi keinginan mereka mengikuti jaman. Inilah prilaku konsumtif masyarakat menarik diteliti.

Di era modern, perilaku konsumtif di kalangan masyarakat berkembang pesat, orang cenderung membeli barang yang tidak dibutuhkan melainkan hanya karena keinginan untuk memiliki (Enrico et al., 2014).

Perilaku konsumtif ini biasanya menjelaskan keinginan seseorang untuk mengkonsumsi suatu barang secara berlebihan yang sebenarnya sedang tidak ia butuhkan, sehingga perilaku konsumtif mengarah pada pemborosan atau menghambur-hamburkan uang, seseorang lebih mendahulukan keinginannya daripada kebutuhannya (Soebiyakto, 1988).

Badan Pusat Statistik (BPS) mencatat bahwa Produk Domestik Bruto (PDB) pada pengeluaran konsumsi rumah tangga triwulan II 2019 yang diukur berdasarkan harga berlaku mencapai $\mathrm{Rp}$ 2.211,3 triliun. Dengan nilai tersebut, konsumsi rumah tangga pada tahun 2019 masih berkontribusi terbesar terhadap perekonomian nasional, yakni lebih dari $55 \%$ dari PDB Nasional. Pertumbuhan tersebut merupakan pertumbuhan yang tertinggi dalam 21 triwulan. Menurut Kepala BPS Suhariyanto, pertumbuhan konsumsi rumah tangga tersebut lantaran adanya kesempatan yang mendorong konsumsi di kuartal II-2019. Seperti waktu Ramadhan, Lebaran, Pemilu hingga THR. Pada data BPS tersebut menunjukkan bahwa tingkat konsumtif masyarakat Indonesia semakin meningkat, dengan diiringi perkembangan jaman dan perkembangan teknologi (Sugiyanto, 2019).

Selanjutnya, Febrianti Dwi Lestari dalam pemaparannya pada Seminar Nasional Sosiologi Perkotaan Ketahanan Energi Kota pada November 2013 mengatakan bahwa 3 dari 5 masyarakat di Solo tergolong dalam masyarakat konsumtif irrational, sulit dinalar secara ekonomi terjadi di 5 kecamatan di Solo, termasuk Banjarsari, Laweyan, Serengan, Pasar Kliwon, dan Jebres. Di daerah ini sebanyak 60 persen perilaku masyarakat adalah konsumtif irrational dan sisanya sebanyak 40 persen adalah konsumtif rasional. Pola perilaku konsumtif ini disebabkan oleh ketergantungan teknologi dan konsumtif BBM (Bahan Bakar Minyak) untuk transportasi. Derajad (2013) menilai bahwa sifat dan prilaku konsumtif masyarakat Solo tergolong tinggi.
Seseorang yang konsumtif, akan membeli barang hanya karena mengikuti sesuatu yang sedang diminati, dan lambat laun barang itu sudah tidak menjadi hal yang diminati lagi dan tidak terpakai lagi. Mereka akan mulai bosan, yang pada akhirnya barang-barang yang dibeli berakhir menjadi limbah, yang sebenarnya masih dalam kondisi baik. Hal ini yang seharusnya perlu diatasi oleh berbagai komunitas-komunitas sosial yang peduli prilaku hemat dan menghindari sifat boros. Komunitas masyarakat harus mencegah dan menanggulangi laju perilaku konsumtif, mulai dari keluarga dan lingkungan sosial terdekat.

Komunitas adalah kesatuan sosial
dalam organisasi kelompok yang (communities of common interest). Pada dasarnya komunitas merupakan bagian dari sebuah masyarakat (Lestari \& Kamil, 2018). Pada komunitas terdapat interaksi-interaksi yang dilakukan secara intensif. Komunitas terbentuk akibat adanya pengalaman, minat yang sama, sikap dan kegemaran antar individu yang kemudian dibentuk suatu wadah sebagai tempat keberlangsungan komunitas dan untuk mengapresiasikan kegiatan-kegiatannya. Setiap komunitas memiliki ciri masing-masing yang dapat membedakan dengan komunitas lainnya, ciri khas dalam komunitas terletak pada kegiatan-kegiatan yang dilakukan yakni, minat pada komunitas tersebut, hobi, atau tempat komunitas tersebut berada. Dalam sebuah komunitas para anggotanya biasanya bersifat sukarela (Rini, 2016).

Keberadaan sebuah komunitas sosial peduli hemat, anti mubazir, semakin meluas di seluruh Indonesia. Perkembangan komunitas sosial ini juga ada di Kota Surakarta, salah satunya komunitas Joli Jolan. Komunitas Joli Jolan merupakan komunitas yang berlokasi di Laweyan, Surakarta, sebagai tempat berkumpulnya para anggota yang memiliki sifat sosial yang tinggi. Para anggota Komunitas Joli Jolan dari berbagai kalangan, yakni dari mahasiswa, Jurnalis, Guru, Pekerja, maupun ibu rumah tangga. Komunitas ini memberi wadah bertukar barang, dan namanya "Joli Jolan" terinspirasi dari bahasa jawa ijol ijolan yang berarti tukar menukar. Setiap orang dapat tukar menukar barang yang ia punya dengan barang yang ada di tempat Joli Jolan. Pada komunitas Joli Jolan juga memiliki berbagai kegiatan 
kemasyarakatan, yang terkadang juga membuat kolaborasi dengan komunitas lain yang memiliki tujuan yang sama.

Peneliti mengkaji bagaimana Peran Komunitas Joli Jolan dalam masyarakat konsumtif di Surakarta dengan menggunakan teori Pertukaran Sosial Peter M Blau.

\section{METODE}

Komunitas Joli Jolan yang beralamat di Jl. Siwalan, Kerten, Laweyan, Surakarta. Penelitian dilakukan selama 8 bulan, Juni 2020 - Januari 2021, dari proses penyusunan proposal hingga penyusunan laporan akhir. Penelitian ini menggunakan penelitian kualitatif dengan pendekatan studi kasus yang dilaksanakan di Komunitas Joli Jolan di Surakarta. Kualitatif merupakan proses untuk menggali sebuah informasi serta kondisi yang sebenarnya terjadi dalam kehidupan suatu objek yang diteliti dan dihubungkan dengan pemecahan masalah baik dari sudut pandang teoritis ataupun dari sudut pandang praktis (Nawawi, 1993). Sedangkan studi kasus adalah pengkajian secara terperinci yang perhatiannya memusatkan pada suatu objek tertentu untuk dikaji secara mendalam yang nantinya akan menemukan sebuah realitas.

Pengumpulan data dilakukan dengan wawancara, observasi, dan dokumentasi. Wawancara dilakukan kepada 12 informan yakni 1 pelopor komunitas, 4 anggota komunitas dan 7 pengunjung komunitas, dengan menggunakan wawancara semistructured untuk mengumpulkan data ide dasar Joli Jolan dari pelopor, alasan anggota komunitas, motivasi pengunjung bergabung dengan Joli Jolan. Observasi untuk melihat interaksi pengunjung dan anggota komunitas Joli Jolan ketika kegiatan tukar menukar barang, Workshop, dan Food Not Booms. Sedangkan, dokumentasi menggunakan foto kegiatan komunitas Joli Jolan, pembukuan, data keuangan inventarisasi dan kearsipan kegiatan.

Penelitian telah menggunakan teknik purposive sampling. Teknik ini merupakan pemilihan atau seleksi terhadap orang atau tempat yang dapat membantu memahami fenomena Joli Jolan (Creswell, 2014). Kriteria informan anggota harus memahami seluk beluk komunitas Joli Jolan. Sedangkan informan pengunjung adalah orang yang sudah pernah mengunjungi atau baru pertama kali mengunjungi komunitas Joli Jolan, baik remaja atau dewasa.
Peneliti menggunakan triangulasi sumber karena peneliti dapat menggunakan hasil wawancara dari beberapa informan tersebut untuk membandingkan dengan apa yang didapat dari informan utama yaitu komunitas Joli Jolan dan informan pendukung yaitu pengunjung dari komunitas Joli Jolan. Selain itu dengan triangulasi tersebut didapatkan hasil data wawancara, dokumentasi, dan observasi yang berkaitan dan dapat menjawab masalah tersebut.

\section{HASIL DAN PEMBAHASAN}

Hasil penelitian ini membahas mengenai komunitas Joli Jolan, penyebab masyarakat berperilaku konsumtif dan komunitas Joli Jolan dalam mencegah perilaku konsumtif.

\section{Komunitas Joli Jolan}

Komunitas Joli Jolan merupakan komunitas sosial yang memberikan ruang solidaritas pada masyarakat untuk saling berinteraksi tanpa sekat identitas, suku, jender dan kelas sosial. Komunitas Joli Jolan terletak di daerah Laweyan, Surakarta. Sarana yang diberikan pada masyarakat adalah tukar menukar barang. Anggota komunitas Joli Jolan membuat sebuah komunitas karena prihatin terhadap perilaku konsumtif masyarakat saat ini. Hal inilah yang menjadikan para anggota membuat komunitas Joli Jolan dengan tujuan menekan sikap konsumtif masyarakat dengan mengadakan berbagai kegiatan. Komunitas Joli Jolan memiliki beberapa kegiatan.

Kegiatan pertama yakni Tukar Menukar Barang, Joli Jolan membuka ruang untuk masyarakat saling tukar menukar, kegiatan ini merupakan kegiatan utama dari komunitas Joli Jolan. Joli Jolan bukan lembaga charity yang mengumpulkan bantuan untuk disalurkan penerima manfaat, akan tetapi yang menjadi fokus Joli Jolan adalah barang-barang yang masih memiliki masa manfaat dan masih dalam kondisi layak serta sudah tidak lagi dimanfaatkan oleh pemiliknya sehingga bisa saling ditukarkan.

Kegiatan tukar menukar barang di Komunitas Joli Jolan dilakukan pada setiap hari Rabu dan Sabtu dari pukul 10.00 hingga 15.00 WIB. Kegiatan ini dibuka untuk umum, dari anak kecil sampai orang lanjut usia bisa datang ke Joli Jolan untuk bertukar barang. Kegiatan Joli Jolan tidak memandang kelas sosial masyarakat. Semua masyarakat bisa datang dan bertukar barang di Joli Jolan. 
Barang yang dikumpulkan komunitas Joli Jolan untuk kegiatan tukar menukar barang yakni barang-barang yang masih layak digunakan dan masih memiliki manfaat, barang-barang yang dikumpulkan berupa pakaian, buku bacaan, perlengkapan rumah tangga, perkakas, hiasan rumah, keperluan hewan peliharaan, barang koleksi, dan juga bisa berupa makanan.

Dalam kegiatan tukar menukar barang, pengunjung dapat hanya mendonasikan barangnya tanpa mengambil atau menukarkan barang yang ada, selain itu pengunjung juga dapat hanya mengambil barang yang ada tanpa membawa atau menukarkan barang miliknya, akan tetapi dilain hari pengunjung dapat membawa barang untuk didonasikan.

Sistem tukar menukar di Joli Jolan sudah ditentukan terlebih dahulu, di mana masyarakat bisa tukar menukar selama dua minggu sekali serta diberi batasan dalam pengambilan barang yakni maksimum pengambilan 3 barang.

Selanjutnya kegiatan kedua Komunitas Joli Jolan adalah Food Not Booms, kegiatan ini merupakan kegiatan berbagi makanan yang dilakukan di ruang Joli Jolan. Food Not Booms ini dilakukan dengan memberikan stand kecil untuk tempat makanan dari para donatur, siapapun bisa memberi makanan maupun sembako di stand yang telah disediakan dan siapapun juga dapat mengambil makanan yang ada.

Kegiatan ketiga pada Komunitas Joli Jolan yakni Workshop dan Sosialisasi, Pada kegiatan ini Joli Jolan membuat kegiatan sosialisasi dengan mengundang masyarakat untuk berpartisipasi dalam kegiatan sosial. Kegiatan-kegiatan sosialisasi yang dilakukan Komunitas Joli Jolan dengan berbagai tema yakni tema sosial, pendidikan, dan lainnya.

Selain itu Joli Jolan juga mengadakan kegiatan Workshop mengenai pertanian dan lainnya yang ditujukan untuk masyarakat umum. Masyarakat mengikuti workshop secara berbayar. Dana terkumpul menjadi donasi untuk Joli Jolan dalam membiayai kegiatan Food Not Booms, santunan di panti asuhan dan sebagainya.

Kemudian kegiatan lainnya adalah berbagi susu untuk anak-anak yang mengunjungi Joli Jolan. Kegiatan ini dilakukan setiap hari Rabu di ruang Joli Jolan. Tujuannya yakni agar anak-anak dapat memenuhi kebutuhan nutrisinya. Selain keempat kegiatan tersebut Joli Jolan juga berkolaborasi dengan beberapa komunitas lainnya seperti komunitas kucing di Solo, Komunitas Reptil, dan juga Barbershop. Semua ini untuk memperluas saranan kegiatan masyarakat. Komunitas Joli Jolan juga membuka ruang baca dengan koleksi buku berkualitas untuk meningkatkan kualitas literasi warga. Joli Jolan memberi ruang bermain anak sebagai sarana interaksi anak-anak.

Dari beberapa kegiatan tersebut Komunitas Joli Jolan berusaha dapat menekan perilaku konsumtif masyarakat dengan menyuarakan melalui media sosialnya dan mengajak masyarakat untuk mengikuti kegiatan di Joli Jolan, dengan kegiatan tukar menukar barang, masyarakat tidak perlu lagi membeli barang di luar sana, sehingga masyarakat dapat lebih menghemat uang mereka, serta Komunitas Joli Jolan mengajak masyarakat agar dapat memanfaatkan uang mereka untuk hal positif yakni dengan mengikuti kegiatan Workshop.

Dengan adanya kegiatan-kegiatan yang diadakan komunitas Joli Jolan, pengunjung merasa lebih menghemat pengeluaran mereka dalam berbelanja serta menyadarkan mereka untuk saling berbagi dan tidak berperilaku konsumtif. Wahyu, menyatakan bahwa "dengan adanya tukar menukar ini saya menjadi bisa lebih menghemat, sebelum ada Joli Jolan anak selalu minta dibelikan mainan, saya lihat baju bagus saya beli, padahal waktu itu mainan anak masih bagus, baju-baju saya juga masih ada, jadi lebih boros karena belibeli barang yang sebenarnya tidak diperlukan saat itu. Setelah ruang ini ada saya jadi bisa mengurangi pengeluaran saya, tidak perlu beli lagi tapi bisa ditukarkan dengan barang yang ada di Joli Jolan." (Wahyu, 11 November 2020)

Pengunjung merasa diuntungkan karena mereka mendapatkan barang yang mereka inginkan dalam kegiatan tukar menukar. Bahkan, mereka mendapatkan makanan dari kegiatan Food Not Booms. Kita cermati pernyataan Ani berikut "adanya Komunitas ini saya tidak merasa dirugikan, karena bisa menghemat pengeluaran saya, saya jadi tidak boros karena bisa menukar dengan barang-barang yang disini, anak juga bisa ambil mainan dari sini tanpa membeli, adanya komunitas ini menurut saya orangorang jadi lebih menghemat pengeluaran mereka". (Ani, 24 Oktober 2020)

Pengunjung merasa bahwa Komunitas Joli Jolan adalah komunitas sosial yang 
bermanfaat bagi masyarakat. Saat ini masyarakat menganggap bahwa komunitas Joli Jolan adalah komunitas sosial yang sangat popular dan bermanfaat.

\section{Penyebab Masyarakat Berperilaku Konsumtif \\ Perilaku konsumtif adalah sifat} alamiah yang dimiliki oleh semua orang yang tidak dapat dipisahkan dalam kehidupan sehari-hari (Hidayat et al., 2018). Kemudian, Mahrunnisya menegaskan bahwa banyak perilaku membeli dan menggunakan barang tanpa dilandasi dengan pertimbangan akal rasional, cenderung mengkonsumsi secara berlebihan, dan lebih mementingkan faktor keinginan daripada kebutuhan (Mahrunnisya et al., 2018).

Penyebab seseorang berperilaku konsumtif karena berbagai faktor. Salah satu penyebab konsumtif tersebut adalah berkembangnya teknologi yang memunculkan berbagai fitur-fitur yang memudahkan untuk melakukan suatu kegiatannya. Perkembangan teknologi ini memunculkan berbagai online shop seperti online shop melalui Instagram, Facebook, WhatsApp dan online shop lainnya, hal ini lah yang menyebabkan masyarakat dapat berbelanja dengan mudah, dengan kemudahan berbelanja tersebut yang menjadikan masyarakat menjadi memiliki sifat konsumtif.

Pengunjung pada penelitian ini mengaku bahwa adanya online shop yang menjadikan mereka berbelanja secara berlebihan karena adanya berbagai macam produk dan kemudahan untuk berbelanja yang ada pada online shop. Seperti pernyataan Tina Sebagai berikut, "saya punya aplikasi online shop lazada dan shopee, dulu kadang suka lihat baju-baju shopee bagus-bagus jadi tertarik, produk juga berbagai macam, ada diskon juga, apalagi kadang iklan di televisi saat diskon besar-besaran seperti acara shopee, barang juga bagus-bagus, baju kadang ada yang lagi trendy saya beli, barang dapur juga saya tertarik beli, jadi pas ada diskon malah pengeluaran banyak..." (Tina,14 November 2020)

Mereka merasa bahwa dengan kemudahan berbelanja tersebut yang menyebabkan boros dalam berbelanja. Gawai bukan hanya alat komunikasi biasa bahkan gawai bisa menjadi bagian dari hidup kita yang sangat penting (Usni et al., 2019).
Masyarakat dapat melihat suatu produk hanya dengan melihat gawai yang dimiliki, dan transaksi jual beli yang mudah juga dapat diakses dalam gawai, kemudahan inilah yang menyebabkan timbulnya perilaku konsumtif. Seperti Pernyataan Ani, sebagai berikut "awal bulan kan pas udah nerima gaji, kadang suka khilaf beli-beli di toko sama di online shop, saat ini mudah beli apa-apa lewat hp bisa, bayar lewat hp juga bisa..."(Wahyu, 11 November 2020)

Penyebab lain yang menimbulkan sifat konsumtif pengunjung adalah dengan adanya iklan dan promo menarik yang menyebabkan masyarakat tertarik untuk membeli suatu produk. Pengunjung Tiara pada penelitian ini mengaku membeli barang saat ada event diskon besarbesaran yang diadakan online shop. "saya salah satu pengguna online shop, karena banyak promo gratis ongkir dan kadang juga harga lebih murah dari di toko, tanggal 9.9 10.10 itukan banyak diskon, dari situ saya jadi beli barang yang sebenarnya tidak saya butuhkan, jatuhnya saya jadi boros, karena termakan iklan dan promo, dan mudah juga kan beli di olshop, apalagi bisa transfer melalui hp juga" (Tiara, 11 November 2020)

Hal tersebutlah yang menjadikan konsumtif pada masyarakat yang sebenarnya membeli barang yang sedang tidak dibutuhkan pada saat itu. Adanya promo dan diskon tersebut telah menjadikan informan tertarik membeli. Mereka merasa bahwa harga lebih murah dari biasanya. Dengan dikemas dengan iklan yang menarik membuat masyarakat antusias membeli suatu produk yang diiklankan. Iklan televisi memberikan informasi adanya diskon besarbesaran, hal tersebut menjadikan masyarakat untuk boros.

Hal lain yang menyebabkan munculnya sifat konsumtif adalah faktor lingkungan, di mana informan pengunjung Joli Jolan cenderung mengikuti apa yang sedang ada di lingkungannya. Salah satu pengunjung Damai menjadi konsumtif karena mengikuti apa yang sedang trendy waktu itu di lingkungannya, "kadang suka beli baju, tas, sepatu yang lagi trend gitu yang dipakai teman-teman juga, jadi kadang tertarik beli, menabung dulu, hasil tabungan biasanya buat beli apa yang aku mau, saya juga punya aplikasi online shop kan, banyak ragam tas sepatu, kadang beli di online shop kadang juga beli lewat Instagram, sama kadang tertarik jualan teman di status whats app"(Damai, 14 November 2020) 
Derasnya arus media promosi telah memunculkan motivasi masyarakat untuk membeli suatu barang yang sebenarnya tidak diperlukan saat itu, melainkan hanya karena ingin memiliki suatu barang tersebut terlebih lagi barang tersebut yang sedang trendy waktu itu. Adanya motivasi tersebut mendorong perilaku konsumtif seseorang, dengan adanya motivasi yang tinggi untuk membeli suatu produk, seseorang akan cenderung membeli tanpa menggunakan faktor rasionalnya (Kotler, 2000). Informan di sini mengaku bahwa dia tertarik produk yang dipakai teman-temannya yang menjadikan mereka juga tertarik untuk membeli. Hal yang ada di lingkungan tersebutlah yang menyebabkan masyarakat cenderung berperilaku konsumtif.

Dari Hal tersebut terlihat bahwa pengunjung Joli Jolan berperilaku konsumtif karena berbagai faktor yakni kemajuan teknologi yang memudahkan dalam berbelanja, dengan adanya online shop, Mobile banking dan sebagainya. Faktor yang lainnya yaitu adanya diskon, iklan serta promo yang menarik yang membuat pengunjung Joli Jolan tertarik membeli produk. Trending products tertentu telah membuat pengunjung termotivasi untuk membeli suatu produk karena sedang populer dilingkunganya.

Tabel 1. Penyebab Perilaku Konsumtif

\begin{tabular}{|l|l|}
\hline Penyebab Konsumtif & Persentase \\
\hline $\begin{array}{l}\text { Kemajuan Teknologi: Adanya } \\
\text { Online Shop }\end{array}$ & $50 \%$ \\
\hline Diskon, Iklan dan Promo & $33 \%$ \\
\hline Faktor Lingkungan & $16 \%$ \\
\hline
\end{tabular}

Berdasarkan Tabel 1, penyebab perilaku konsumtif, baik anggota maupun pengunjung ditemukan hasil bahwa 50\% informan mengaku perilaku konsumtif disebabkan karena adanya kemajuan teknologi seperti adanya online shop, Mobile Banking yang memudahkan dalam berbelanja, dan 33\% Informan mengaku adanya diskon, iklan dan promo memunculkan ketertarikan untuk berbelanja sehingga mengakibatkan munculnya perilaku konsumtif, serta $16 \%$ informan mengaku berperilaku konsumtif karena dorongan dari lingkungan.

Berbeda dengan penelitian milik Nurul Wahidah, pada penelitiannya penyebab perilaku konsumtif karena gaya hidup seseorang akibat tuntutan pergaulan (Wahidah, 2013). Sedangkan pada penelitian ini perilaku konsumtif muncul karena kecanggihan teknologi yang meunculkan online shop.

\section{Komunitas Joli Jolan Mencegah Perilaku Konsumtif}

Berbeda dengan penelitian milik Nooriah Mujahidah, pada penelitiannya penanganan perilaku konsumtif dengan menggunakan Teknik Self-Management, yakni teknik yang mengarahkan konseling untuk dapat mengubah tingkah lakunya ke arah yang lebih efektif sesuai dengan yang diinginkan dengan menggunakan satu strategi atau gabungan beberapa strategi untuk dapat mencegah perilaku konsumtif (Mujahidah et al., 2020).

Sedangkan pada penelitian ini dimana upaya pencegahan perilaku konsumtif pada masyarakat yang dilakukan Komunitas Joli Jolan melalui beberapa kegiatan yang dilakukan dengan dianalisis menggunakan teori pertukaran sosial Peter M. Blau, yang mana hasil dari penelitian menunjukan bahwa informan dapat mengurangi perilaku konsumtif mereka dengan mengikuti kegiatan yang diadakan di Joli Joan.

Peran yang dilakukan komunitas Joli Jolan dalam masyarakat konsumtif sesuai dengan Teori Pertukaran Sosial yang dikemukakan oleh Blau. Pada teori Pertukaran Sosial manusia selalu pada hubungan pertukaran antar satu dengan yang lain, baik individu dengan individu maupun individu dengan kelompok. Hubungan sosial yang terjadi dalam masyarakat memiliki perilaku yang saling mempengaruhi satu sama lain di mana dalam hubungan tersebut terdapat imbalan, pengorbanan dan keuntungan. Pengorbanan yang dilakukan pengunjung Joli Jolan itu adalah mendonasikan barang miliknya sedangkan imbalan yang didapat adalah dengan menukar barang yang ada di Ruang Joli Jolan.

Sedangkan pengorbanan pada anggota komunitas Joli Jolan berupa kesukarelaan memberikan waktu dalam melaksanakan kegiatan Joli Jolan. Misalnya, "Saya kan bekerja juga, jadi saya bisanya datang saat sabtu, atau saat saya longgar, jadi anggota dapat kapanpun datang untuk membantu dengan sukarela..." (Ika, 21 Oktober 2020)

Sedangkan imbalan dan keuntungan yang anggota dapat adalah pujian dari masyarakat serta dapat berinteraksi dengan masyarakat lain. Misalnya “...kita dapat pujian dari masyarakat, kita menjadi 
komunitas sosial yang dikenal masyarakat."( Chrisna, 17 Oktober 2020)

Anggota Komunitas Joli Jolan Faisal juga mengaku dengan bergabung menjadi anggota komunitas, Faisal mendapatkan banyak teman. Berikut ini pernyataan Faisal "Bergabung disini jadi memiliki banyak teman, tambah-tambah anggota tambah teman, relasi pertemanan semakin luas..." (Faisal. 21 Oktober 2020).

Pertemanan adalah hakekat kehidupan sosial. Interaksi itu sendiri adalah kunci dari kehidupan bersosial karena tanpa ada interaksi, tidak mungkin ada kehidupan bersama atau berkelompok (Azizah et al., 2020).

Konsep Blau terbatas pada tingkah laku yang mendatangkan imbalan, yaitu tingkah laku akan berlanjut jika seseorang mendapatkan imbalan dan akan berhenti jika seseorang merasa dan beranggapan tidak akan ada imbalan lagi yang diperolehnya. Tingkah laku tersebut terjadi saat kegiatan Joli Jolan berlangsung, di mana masyarakat yang berkunjung di Joli Jolan merasa diuntungkan sehingga masyarakat terus mengikuti kegiatan yang diadakan komunitas Joli Jolan. Pengunjung mendapatkan imbalan berupa barang, seperti pernyataan Tina sebagai berikut "Nggak bisa dihitung sudah berapa kali ke sini, saya bakal datang lagi ke sini untuk menukar barang, karena disini saya diuntungkan juga." (Tina, 11 November 2020). Blau berusaha menggabungkan antara teori mikro dan makro, Blau menandai terdapatnya ketergantungan antara pertukaran sosial pada tingkat mikro dan munculnya struktur sosial yang lebih makro (Blau, 1986).

Pada tingkat mikro Blau membedakan imbalan intrinsik dan ekstrinsik. Bagi Blau fenomena daya tarik individu terhadap imbalan adalah sesuatu yang bersifat "given" yang membuat tertarik individu adalah imbalan ekstrinsik (seperti uang atau barang-barang material lainnya) maupun imbalan intrinsik (seperti cinta, kasih sayang, pujian, perhatian dan penghargaan (Blau, 1986).

Pada hasil penelitian menjelaskan bahwa imbalan ekstrinsik didapat pengunjung Joli Jolan dan komunitas Joli Jolan. Pengunjung Joli Jolan mendapatkan imbalan ekstrinsik berupa barang dalam melakukan kegiatan tukar menukar di Joli Jolan. Misalnya, "Saya waktu itu butuh beli buku bacaan, saya datang ke sini dan kebetulan buku yang saya cari ada, jadi saya tidak perlu beli buku, datang ketiga kalinya, saya ingin tanam menanam, kebetulan di Joli Jolan ada bibit, saya ambil dan saya tukarkan dengan barang saya, biasanya saya bawa buku sama pakaian" (Tiara, 11 November 2020)

Dalam kegiatan tukar menukar ini pengunjung menukarkan barang yang mereka miliki dengan ditukar barang yang ada di ruang Joli Jolan. Pada kegiatan tukar menukar berbeda dengan barter karena pengunjung dapat menukarkan barangnya tanpa melihat nilai barang tersebut. Pengunjung dapat menukarkan barang dengan nilai yang lebih tinggi dari barang yang ia tukarkan. Inilah pengunjung mendapatkan imbalan ekstrinsik, yaitu mendapatkan barang yang diinginkan di ruang Joli Jolan.

Selain kegiatan tukar menukar imbalan ekstrinsik yang didapat oleh pengunjung Joli Jolan adalah makanan pada kegiatan Food Not Booms. Pada kegiatan tersebut Joli Jolan menyediakan sebuah wadah untuk berbagi makanan pada masyarakat. Selain mendapatkan barang masyarakat juga bisa mendapatkan makanan yang ada di Joli Jolan.

Pada komunitas Joli Jolan juga mendapat imbalan ekstrinsik dari pengunjung. Imbalan tersebut berupa uang donasi yang didapat dari pengunjung dalam melakukan kegiatan workshop, uang donasi tersebut yang akan digunakan komunitas Joli Jolan dalam mengembangkan kegiatankegiatan yang ada di Joli Jolan, seperti membeli rak untuk wadah barang donasi, membuat makanan untuk kegiatan food not booms dan lain-lain. Seperti pernyataan Faisal sebagai berikut, "kita juga dapat donasi-donasi barang serta makanan untuk keberlangsungan kegiatan dan workshop kita berbayar dan uang yang didapat nanti buat donasi memajukan Joli Jolan, seperti buat makanan untuk kegiatan Food Not Booms dan kegiatan lain," (Faisal, 21 Oktober 2020)

Sedangkan imbalan intrinsik berupa cinta, kasih sayang, pujian, keramahan, perhatian dan penghargaan yang didapatkan oleh individu. Pada penelitian ini imbalan intrinsik berupa keramahan, pujian dan kepedulian didapat pengunjung dan komunitas Joli Jolan.

Imbalan intrinsik yang didapat pengunjung Joli Jolan yakni berupa sebuah perhatian pada saat kegiatan Joli Jolan dilakukan. Pengunjung Joli Jolan mendapat 
sebuah perhatian serta kasih sayang dari para anggota komunitas Joli Jolan.

Seperti pernyataan Wahyu sebagai berikut, "Anggotanya ramah-ramah, saya juga merasa anggota komunitas Joli Jolan peduli dengan kita, perhatian juga sama kita ditanya bagaimana keadaan saya, kondisi saya, dari situ terlihat anggota ramah. Peduli pada saya."(Wahyu, 11 November 2020)

Selain itu, imbalan intrinsik tersebut yakni saat pengunjung datang, para anggota akan menyambut dengan ramah, para anggota tidak membedakan kelas sosial para pengunjung. Para anggota komunitas Joli Jolan juga terbuka untuk mendengar ceritacerita dari pengunjung Joli Jolan, sehingga para pengunjung merasa nyaman dan merasa disayang oleh anggota komunitas Joli Jolan.

Misalnya, “...kakak-kakak Joli Jolan enak buat diajak cerita, ramah baik, kadang ada novel baru bilang sama saya..." (Damai 14 November 2020)

Anggota komunitas Joli Jolan juga dengan senang hati berusaha membantu para pengunjung yang sedang mengalai kesusahan yakni seperti beberapa pengunjung yang sedang membutuhkan sembako, komunitas Joli Jolan akan membantu dengan memberikan sembako dari uang donasi yang ada di Joli Jolan.

Seperti pernyataan Ani sebagai berikut, "...teman saya ada yang butuh sembako, bilang sama Joli Jolan, Alhamdulillah Joli Jolan mau membantu, menyumbangkan sembako, anggotanya ramah-ramah, kegiatannya juga bagus" (Ani, 24 Oktober 2020)

Sedangkan anggota komunitas Joli Jolan juga mendapat imbalan intrinsik berupa pujian dari para pengunjung Joli Jolan maupun dari masyarakat.

Imbalan tersebut berupa sebuah pujian dari masyarakat bahwa Komunitas Joli Jolan merupakan komunitas yang bermanfaat. Seperti pernyataan Chrisna sebagai berikut, "kita dapat pujian dari masyarakat sebagai komunitas yang bermanfaat, kita menjadi komunitas sosial yang dikenal masyarakat." (Chrisna, 17 Oktober 2020)

Imbalan intrinsik tersebut yakni para pengunjung Joli Jolan selalu berterimakasih pada komunitas Joli Jolan karena telah membuat sebuah ruang tukar menukar tanpa memandang kelas sosial masyarakat, para pengunjung selalu memuji bahwa komunitas Joli Jolan dapat membantu masyarakat dalam kegiatan yang ada di Joli Jolan, kegiatan-kegiatan yang dilakukan Joli
Jolan dianggap positif oleh masyarakat, dari kegiatan tukar menukar, Food Not Booms maupun kegiatan workshop.

Hal tersebutlah merupakan imbalan intrinsik yang didapat dari komunitas Joli Jolan. Seperti pernyataan pengunjung Putri yang memuji Komunitas Joli Jolan sebagai berikut, "Mereka membuat kegiatankegiatan yang sangat baik dan bermanfaat, mengajarkan kita bersedekah, mengajarkan kita untuk bisa memanfaatkan barang kita dengan baik, secara tidak langsung Komunitas Joli Jolan mengajarkan agar tidak boros" (Putri, 10 Desember 2020)

Selanjutnya Blau menandai terdapatnya ketergantungan antara pertukaran sosial pada tingkat mikro dan munculnya struktur sosial yang lebih makro. Pada tingkat mikro adalah imbalan berupa intrinsik dan ekstrinsik, pada hal tersebut menjadikan hal yang kompleks ke arah yang lebih makro yakni sebuah struktur sosial yang mengarah pada kekuasaan yang diperoleh setelah pada tingkat mikro.

Ketergantungan pada tingkat mikro ke makro yakni pengunjung akan datang kembali pada kegiatan yang diadakan karena merasa diuntungkan, hal tersebut menjadikan komunitas Joli Jolan dapat mewujudkan tujuannya dalam menekan perilaku konsumtif masyarakat dengan mengadakan serangkaian kegiatankegiatan tersebut.

Pada tingkat makro sebenarnya tidak secara langsung dapat menjelaskan keadaan Joli Jolan. Dalam analisis makro Sosiologi mencangkup pola hubungan sosial terutama orang-orang dari posisi sosial yang berbeda. Melalui proses pertukaran sosial maka timbul pertukaran seimbang atau tidak seimbang. Apabila pertukaran dirasa seimbang maka dapat terjadi hubungan saling ketergantungan atau timbal balik. Akan tetapi apabila pertukarannya tidak seimbang maka yang muncul adalah perbedaan status dan kekuasaan. Seseorang yang memiliki kekuasaan atas orang lain dengan mengontrol sumber- sumber penghargaan di mana mereka menjadi tergantung, mampu untuk membangun suatu garis tindakan kelompok dalam hubungannya dengan orang atau kelompok lain. Hal tersebutlah merupakan dasar munculnya struktur makro.

Pada bagian makro, saat terjadinya pertukaran tidak seimbang pada komunitas Joli Jolan dengan pengunjung saat terjadi kegiatan pertukaran barang, tidak mengarah 
pada perbedaan status dan kekuasaan, karena di Joli Jolan tidak mempunyai struktur organisasi dan anggota dianggap sama.

Seperti pernyataan anggota Chrisna sebagai berikut, "Pada Komunitas Joli Jolan tidak ada struktur organisasi, karena semua dianggap sama, para pengunjung juga kita perlakukan sama, kita tidak memandang dari kelas sosial mereka" (Pelopor Chrisna, 17 Oktober 2020)

Semua anggota dianggap setara, serta pada anggota dan pengunjung Joli Jolan secara sukarela dalam melaksanakan kegiatan, Joli Jolan juga tidak membedakan kelas sosial dari pengunjung, dan juga tidak merasa bersaing dengan komunitas lainnya.

Seperti pernyataan anggota Faisal yang secara sukarela membantu kegiatankegiatan Joli Jolan, sebagai berikut "Komunitas juga tidak ada rekrutmen kan, siapapun bisa bergabung, ikut bantu kegiatan Joli Jolan, datang dengan sukarela, juga tidak ada proker yang ada deadlinenya, jadi kita bisa kapanpun datang dengan sukarela, membantu kegiatan Joli Jolan" ( Faisal, 21 Oktober 2020)

Bahkan pengunjung juga dengan sukarela mendonasikan barang tanpa ada paksaan dari Komunitas Joli Jolan. Seperti pernyataan Wahyu sebagai berikut, "Sama sekali tidak dirugikan dan tidak ada paksaan, barang dirumahkan banyak daripada dibiarkan lebih baik didonasikan bisa lebih bermanfaat lagi..."(Wahyu, 11 November 2020)

Dari hal ini terlihat bahwa tidak adanya kekuasaan yang mendominasi antara komunitas Joli Jolan dengan Pengunjung.

Akan tetapi jika dihubungkan dengan kekuasaan, dari tingkat mikro dimana pengunjung yang mendapatkan imbalan dari Joli Jolan, mengarah pada Komunitas Joli Jolan yang ingin menjadi komunitas yang dapat dikenal seluruh masyarakat sebagai komunitas sosial yang baik. Seperti pernyataan Chrisna sebagai berikut, "harapan kita, agar masyarakat dapat tahu keberadaan komunitas Joli Jolan, melalui media sosial kita menyuarakan komunitas ini agar lebih dikenal masyarakat, masyarakat yang tahu komunitas ini juga akan mengajak teman-teman lainnya agar datang ke Joli Jolan, dari hal ini komunitas menjadi diakui sebagai komunitas sosial, yang sampai didengar stasiun televisi, Joli Jolan jadi diliput, dengan dikenal komunitas Joli Jolan kita dapat mewujudkan tujuan kita" (Chrisna, 17 Oktober 2020)
Pada kekuasaan di sini, Komunitas Joli Jolan lebih ingin mewujudkan tujuannya yakni agar masyarakat tidak bersifat konsumtif. Pada kekuasaannya komunitas Joli Jolan berusaha agar masyarakat mau mengunjungi ruang Joli Jolan, dengan menyuarakan melalui media sosialnya agar masyarakat ikut hadir mengikuti kegiatan Joli Jolan, yang nantinya kekuasaan yang diperoleh Komunitas Joli Jolan adalah sebuah pengakuan sebagai komunitas sosial, yang kemudian komunitas Joli Jolan semakin dikenal masyarakat dan semakin dapat mewujudkan tujuannya. Dengan dikenalnya komunitas Joli Jolan juga menjadikan komunitas Joli Jolan sebagai inspirasi bagi komunitas lain untuk membuat komunitas serupa, yang menjadikan komunitas Joli Jolan sebagai pencetus pertama kegiatan sosial tersebut.

Pada teori ini, apabila seseorang membutuhkan sesuatu dari orang lain, namun tidak dapat memberikan apapun sebagai tukarannya, maka akan terjadi 4 kemungkinan.

Pertama, orang tersebut bisa memaksa orang lain agar dapat membantunya dalam pemenuhan kebutuhannya. Kedua, orang tersebut akan mencari sumber lain yang dapat memenuhi kebutuhannya. Ketiga, orang tersebut dapat mencoba terus bergaul dengan baik tanpa mendapat dan mengharapkan sebuah imbalan dari orang lain. Keempat, orang tersebut dapat menundukkan diri terhadap seseorang yang mampu memberikan penghargaan yang seimbang dengan apa yang telah dilakukan (Ritzer, 2014).

Dari hal tersebut komunitas Joli Jolan berusaha agar dapat mewujudkan keinginannya yakni menekan sifat konsumtif masyarakat, melalui kegiatan- kegiatan yang diadakan, yang dapat menguntungkan bagi masyarakat serta yang membuat masyarakat tertarik sehingga dapat menekan sifat konsumtif masyarakat.

Seperti penyataan Chrisnia sebagai berikut, "Kita membuat tempat ini dengan tujuan biar masyarakat tidak konsumtif, bisa memanfaatkan barang yang mereka miliki dengan sebaik-baiknya, tidak membuang buang barang, dan tidak beli barang yang sekiranya belum dibutuhkan, dan dari ruang ini masyarakat bisa mengurangi pengeluaran mereka, kita menyediakan tempat ini agar masyarakat bisa mengambil barang yang sedang mereka butuhkan tanpa membeli ditempat lain, mereka bisa menukarkan barang yang sudah tidak 
mereka gunakan, dengan barang yang ada di ruang Joli Jolan ini.." (Chrisna, 17 Oktober 2020)

Dengan kegiatan tukar menukar barang di Joli Jolan, pengunjung merasa beruntung karena dapat mengambil barang yang ada di Joli Jolan dengan menukarkan barang miliknya yang sudah tidak terpakai.

Pada relasi ini pengunjung akan mencari sebuah penghargaan, dan penghargaan tersebut terdapat pada Joli Jolan. Pengunjung Joli Jolan menjadi lebih berhemat terhadap pengeluaran ekonomi mereka, pengunjung tidak perlu membeli barang dan menghabiskan uang mereka, tetapi pengunjung dapat mengambil barang yang mereka butuhkan di ruang Joli Jolan, sehingga tujuan dari komunitas Joli Jolan dapat tercapai yakni dapat menekan sifat konsumtif masyarakat, dengan kegiatan yang ada di Joli Jolan.

\section{SIMPULAN DAN SARAN}

Berdasarkan uraian hasil penelitian dan pembahasan di atas mengenai komunitas Joli Jolan mencegah perilaku konsumtif, maka dapat disimpulkan bahwa perkembangan teknologi dan adanya online shop serta pengaruh lingkungan menyebabkan timbulnya perilaku konsumtif seseorang. Komunitas Joli Jolan telah berusaha dan berhasil mencegah masyarakat berprilaku konsumtif.

Masyarakat tidak perlu lagi membeli barang di luar sana akan tetapi dapat bertukar barang di Joli Jolan serta dapat mengelola barang miliknya dengan baik. Joli Jolan juga mengajak masyarakat untuk dapat memanfaatkan uang mereka dengan lebih baik yakni dengan mengikuti workshop sekaligus untuk berdonasi di Joli Jolan.

Sesuai dengan teori pertukaran sosial Peter $M$ Blau, pengunjung mendapatkan imbalan dengan mengikuti kegiatan-kegiatan di Joli Jolan. Imbalan tersebut berupa imbalan ekstrinsik dan intrinsik. Pengunjung mendapat imbalan ekstrinsik berupa barang dari Joli Jolan saat melakukan kegiatan tukar menukar. Secara intrinsik, pengunjung menikmati perhatian dan kasih sayang yang diberikan oleh anggota komunitas Joli Jolan.

Komunitas Joli Jolan juga mendapatkan imbalan ekstrinsik, berupa donasi-donasi dari masyarakat yang berguna mengembangkan komunitas Joli Jolan. Secara intrinsik komunitas Joli Jolan mendapat pujian dari berbagai kalangan masyarakat, populer, pengakuan sosial, sumber inspirasi bagi komunitas lain untuk merubah prilaku boros menjadi prilaku hemat terwujud dalam kehidupan masyarakat.

Akhirnya, peneliti berharap agar gerakan sosial Joli Jolan mencegah prilaku konsumtif dapat menjadi program gerakan pola hidup hemat berkelanjutan di Kota Surakarta dan daerah lainnya.

Serta peneliti juga berharap agar masyarakat tidak menghambur-hamburkan uang untuk sesuatu yang kurang dibutuhkan, alangkah lebih baiknya digunakan dengan hal-hal yang lebih bermanfaat seperti berbagi dengan sesama, selain itu sebaiknya dapat mengelola barang dengan baik, dengan menyumbangkan barang yang sudah tidak dipakai lagi ke orang yang membutuhkan sehingga barang tersebut dapat bermanfaat kembali.

\section{UCAPAN TERIMAKASIH}

Terimakasih atas dedikasi tim penulis Abdul Rahman Ph.D dan Yosafat Hermawan T, S.Sos, M.A, Ph.D dalam menyempurnakan naskah dan mendukung publikasi artikel karya bersama ini.

\section{DAFTAR PUSTAKA}

Azizah, S. N., Purnomo, A., \& Sukamto. (2020). Interaksi Anggota Karang Taruna Bhakti Pertiwi Dalam Pengembangan Wisata Andeman Boonpring $\mathrm{Di}$ Desa Sanankerto Kecamatan Turen Kabupaten Malang. Jurnal IIImu Soslal Dan Humaniora, 9(2), 232. https://doi.org/http://dx.doi.org/10.238 87/jish-undiksha.v9i2.18006

Blau, P. M. (1986). Exchange and Power in Social Life. Transaction Publishers.

Creswell, J. W. (2014). Research Design: Pendekatan Kualitatif, Kuantitatif dan Mixed. PUSTAKA PELAJAR.

Derajad. (2013). 3 Dari 5 Masyarakat Solo Konsumtif Irasional. https://uns.ac.id/id/uns-update/3-dari5-masyarakat-solo-konsumtifirasional.html

Enrico, A., Aron, R., \& Oktavia, W. (2014). The Factors That Influenced Consumptive Behavior: A Survey Of University Students In Jakarta. International Journal of Scientific and Research Publications, 4(1), 2. https://doi.org/10.29322

Hidayat, T. B. W., Punia, I. N., \& Kebayantini, N. L. N. (2018). Peran Media Sosial Terhadap Perilaku 
Konsumtif Kaum Remaja Di Desa Tegal Kertha, Kecamatan Denpasar Barat, Kota Denpasar. Jurnal Ilmiah Sosiologi (Sorot), 1(1), 2. https://ojs.unud.ac.id/index.php/sorot/ article/view/37817

Kotler, P. (2000). Marketing Management, Edisi Milenium,. Prentice-Hall.

Lestari, D. I., \& Kamil, M. (2018). Perilaku Masyarakat Dunia Maya Pada Pelatihan Online Di Komunitas Ibu Profesional. Jurnal IIImu Soslal Dan Humaniora, $7(1), \quad 97$. https://doi.org/http://dx.doi.org/10.238 87/jish-undiksha.v7i1.14160

Mahrunnisya, D., Indriayu, M., \& Kusuma, D. W. (2018). Peer Conformity Through Money Attitudes Toward Adolescence's Consumptive Behavior. International Journal of Multicultural and Multireligious Understanding (IJMMU, 5(4), 33. https://doi.org/http://dx.doi.org/10.184 15/ijmmu.v5i4.163

Nawawi, H. (1993). Metode Penelitian Sosial. Gajah Mada University Pers.

Rini, D. S. (2016). Eksistensi Komunitas Pecinta Reptil Bangka (PERBAK) di Kota Pangkalpinang [Universitas Bangka Belitung]. http://repository.ubb.ac.id/id/eprint/706

Ritzer, G. (2014). Teori Sosiologi edisi 8. Pustaka Pelajar.

Soebiyakto. (1988). Wanita dan Media Massa. Remaja Rosdakarya.

Sugiyanto, D. (2019). Masyarakat RI Masih Doyan Belanja Nih Buktinya. https://finance.detik.com/beritaekonomi-bisnis/d4653100/masyarakat-ri-masih-doyanbelanja-nih-buktinya

Usni, E., Daulay, H., Manurung, R., Ismail, R., \& Sitorus, H. (2019). Gaya Hidup Remaja dan Pengunaan Telepon Seluler di Kota Medan. JUPIIS : Jurnal Pendidikan IImu-IImu Sosial, 11(2), 252.

https://doi.org/https://doi.org/10.24114 /jupiis.v11i2.12811 